УДК 633.85:631.51 (477.4)

DOI https://doi.org/10.32848/agrar.innov.2021.7.18

\title{
ВПЛИВ ФАКТОРІВ ВИРОЩУВАННЯ НА НАРОСТАННЯ НАДЗЕМНОЇ БІОМАСИ РІПАКОМ ОЗИМИМ В УМОВАХ ЛІСОСТЕПУ УКРАЇНИ
}

\author{
ГАМАЮНОВА В.В. - доктор с.-г. наук, професор \\ http://orcid.org/0000-0002-4151-0299 \\ Миколаївський національний аграрний університет \\ ГАРО І.М. - пошукач \\ http://orcid.org/0000-0003-1846-9483 \\ Миколаївський національний аграрний університет
}

Постановка проблеми. Ріст рослин є процесом утворення нових та наростання тих, що вже $є$, елементів структури (молекул, клітин, тканин і органів), що впливають на розподіл, перерозподіл і використання органічних речовин, що утворилися в процесі фротосинтезу та метаболізму [1]. Дослідження процесів росту та розвитку рослин були і залишаються основною проблемою фрізіології рослин та агрономії. За своєю суттю, всі фрізіологічні та агрономічні дослідження мають за кінцеву мету пізнання складних механізмів та законів розвитку рослин, щоб на основі цих знань забезпечувати найбільш сприятливі умови для росту, розвитку і формування врожайності рослин [2]. Знати процеси життєдіяльності рослин і вирішувати завдання закономірностей взаємозв'язку між цими процесами у ході формування врожаю під впливом досліджуваних елементів технології залишаються надзвичайно актуальними.

Аналіз останніх досліджень і публікацій. Інтенсивність фотосинтезу ще не визначає рівня накопичення врожаю, а створює лише необхідні передумови для цього. Хід накопичення біомаси визначається продуктивністю фотосинтезу, тобто продуктивним ростом, фактичним накопиченням сухої речовини за одиницю часу $[3,4]$.

У цьому зв'язку, одним з найважливіших завдань агротехніки є забезпечення такої інтенсивності, масштабності і направленості ростових процесів у рослинах і посівах, за яких досягався б найбільш раціональний, з точки зору вимог виробництва, розподіл по органах рослин продуктів фотосинтезу та метаболізму $[1,5]$. Зважаючи на те, що ріст є одним з найбільш складних процесів за своєю природою, який безперервно, синхронно або з невеликим зсувом фраз у часі копіює хід напруження внутрішніх процесів і зовнішніх фракторів середовища, ми приділили значну увагу вивченню процесу росту ріпаку озимого під впливом основного обробітку ґрунту, строків та способів сівби. Ріст рослин слід розглядати в якості основного фрізіологічного процесу, за масштабами та інтенсивністю якого можна зробити висновки про ступінь оптимізації елементів технології вирощування ріпаку озимого, прийнятих на вивчення $[1,6]$.

Результатами попередніх досліджень авторів визначено, що висота рослин ріпаку озимого значно залежить від способу сівби та густоти стояння травостою. При широкорядному способі сівби рослини мають дещо меншу висоту завдяки великій площі живлення. При звичайному рядковому - вони дещо витягуються, утворюють тонші стебла з меншою кількістю бокових галу- жень [7]. Остаточних показників висота рослин ріпаку озимого досягає під час дозрівання. Але для того, щоб оцінити ефективність того чи іншого елементу технології недостатньо визначити тільки остаточну висоту рослин, а потрібно знати середні показники ростових процесів розвитку сільськогосподарської культури в динаміці.

Метою досліджень передбачали визначити вплив способу і глибини основного обробітку ґрунту під сівбу ріпаку озимого на окремі його показники, зокрема на висоту рослин та накопичення надземної сирої і сухої речовини.

Методика проведених досліджень. Польові й лабораторні дослідження проводили у 2013-2015 рр. в умовах Лісостепу України на чорноземі звичайному, відповідно з методикою польових дослідів та методичних рекомендацій [8, 9].

У трифракторному польовому досліді вивчали продуктивність рослин ріпаку озимого залежно від обробітку ґрунту, строку та способу сівби. Визначали стан розвитку рослин перед виходом у зиму, після перезимівлі, висоту рослин, накопичення надземної сирої і сухої речовини з одиниці площі. До схеми досліду були включені наступні фрактори та їх варіанти:

Фактор А - обробіток ґрунту: 1. Оранка на 25-27 см. 2. Дискування на 12-14 см.

Фактор В - строк сівби: 1. І декада вересня. 2. II декада вересня; 3. III декада вересня.

Фактор С - спосіб сівби (ширина міжрядь): 1.15 см. 2. $30 \mathrm{~cm} ; 3.60 \mathrm{~cm}$.

Дослід закладений методом розщеплених ділянок у відповідності 3 методикою польових дослідів з вивчення агротехнічних прийомів вирощування сільськогосподарських культур. Повторність в досліді чотириразова. Посівна площа ділянки - $80 \mathrm{~m}^{2}$, облікова $50 \mathrm{~m}^{2}$. У досліді висівали новий районований сорт ріпаку озимого Чемпіон України, попередником якого була пшениця озима.

Динаміку росту та розвитку ріпаку залежно від досліджуваних фракторів визначали по трьом основним фазам - стеблування, бутонізація та цвітіння рослин ріпаку озимого згідно методики проведення досліджень.

Результати досліджень. Проведеними біометричними вимірами за фазами розвитку ріпаку озимого визначено, що висота рослин залежала від основного обробітку ґрунту. Слід зазначити, що на початковому етапі розвитку, після відновлення весняної вегетації різниця між варіантами досліду була в межах 5,6\%, у подальшій вегетації вона дещо збільшувалась і склала 7,0\% (рис. 1). 


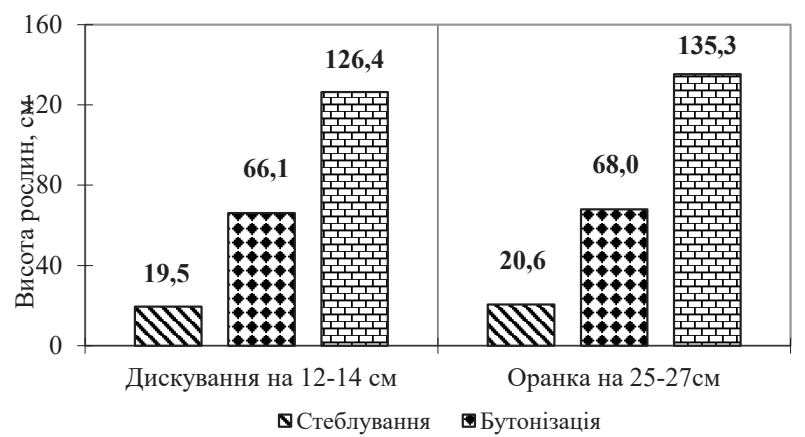

Рис. 1. Висота рослин ріпаку залежно від основного обробітку ґрунту, см (середнє за 2013-2015 рр.)

Як ілюструє рисунок, за всіма фразами розвитку рослини ріпаку озимого найбільшої висоти досягали на посівах, де проводили оранку на 25-27 см. Так, у фазу стеблування висота рослин у цьому варіанті склала 20,6 см, що на 1,1 см більше ніж у варіантах з дискуванням на 12-14 см. У подальшому розвитку ріпаку озимого ця різниця збільшувалась і у фразу бутонізації склала 1,9 см при висоті рослин на посівах з оранкою - 68,0 cм.

Найбільшої висоти рослини ріпаку досягли у фазу цвітіння - 126,4-135,3 см з різницею між варіантами 8,9 см на користь оранки.

Порівнюючи висоту рослин залежно від строку сівби визначено, що відмінності у величині цього показника проявляються вже з фази стеблування. Рослини на посівах у I декаду вересня були вищими на 1,9 см порівняно з сівбою у II декаду та на 4,5 см, ніж у III декаду вересня (рис. 2).

Таку ж закономірність простежували і в подальшому розвитку. У фазу цвітіння ріпаку озимого визначено найбільшу різницю за висотою рослин різних строків сівби. Як видно з рисунку 2, найбільшу висоту - 154,6 см мали рослини, висіяні у I декаду вересня. Більш пізні строки сівби призводили до ії зменшення. Аналізуючи висоту рослин, як основний орган морфологічної структури, можна зазначити різницю цього показника між способами сівби та фазами розвитку ріпаку. Так, у фразу стеблування найвищими - 22,1 см, рослини були за широкорядного способу сівби з шириною міжрядь 60 см. Посіви звичайним рядковим способом та з шириною міжрядь 30 см поступались за висотою на 4,0 cм та 2,1 см відповідно.

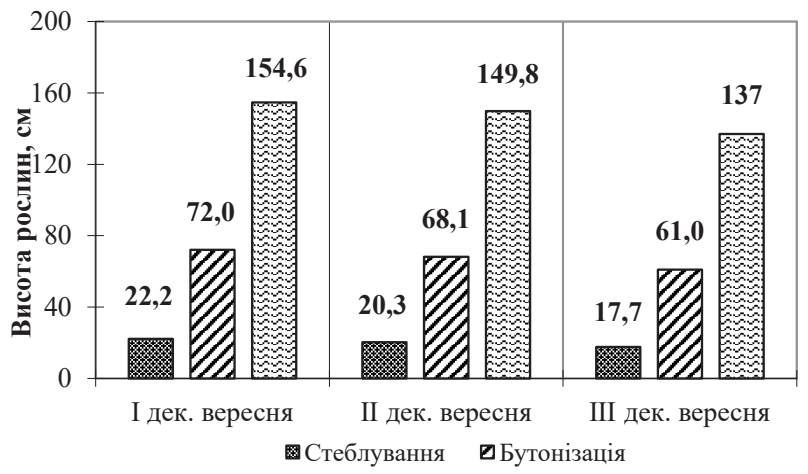

Puc. 2. Bucoma рослин ріпаку залежно від строку сівби, см (середнє за 2013-2015 рр.)

У подальшому розвитку рослин ріпаку ця тенденція змінювалась. Найбільш сприятливі умови для лінійного росту рослин культури складаються на посівах першого строку сівби звичайним рядковим способом, за проведення оранки.

Порівнюючи інтенсивність росту рослин у висоту по періодам розвитку ріпаку озимого у весняно-літній період, слід зазначити, що найбільшою вона була у міжфазний період «бутонізація-цвітіння» (табл. 1). Як свідчать дані таблиці, у цей період середньодобовий

Таблиця 1 - Середньодобовий приріст рослин ріпаку озимого у висоту, см/доба (середнє за 2013-2015 рр.)

\begin{tabular}{|c|c|c|c|c|c|}
\hline \multirow{2}{*}{ Обробіток ґрунту, А } & \multirow{2}{*}{ Строк сівби, В } & \multirow{2}{*}{$\begin{array}{c}\text { Ширина } \\
\text { міжрядь, см, C }\end{array}$} & \multicolumn{3}{|c|}{ Міжфазний період розвитку рослин } \\
\hline & & & $\begin{array}{l}\text { відновлення веге- } \\
\text { тації - стеблування }\end{array}$ & $\begin{array}{l}\text { стеблування } \\
\text { - бутонізація } \\
\end{array}$ & $\begin{array}{c}\text { бутонізація } \\
\text { - цвітіння } \\
\end{array}$ \\
\hline \multirow{9}{*}{ 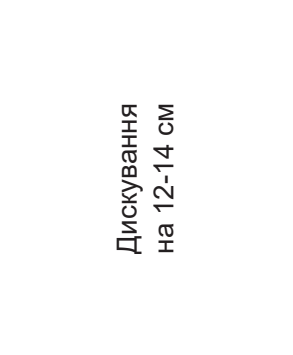 } & \multirow{3}{*}{ І дек. вересня } & 15 & 1,5 & 3,4 & 5,2 \\
\hline & & 30 & 1,5 & 3,3 & 5,4 \\
\hline & & 60 & 1,8 & 2,6 & 5,3 \\
\hline & \multirow{3}{*}{ II дек. вересня } & 15 & 1,2 & 3,6 & 5,2 \\
\hline & & 30 & 1,5 & 3,2 & 4,8 \\
\hline & & 60 & 1,6 & 2,8 & 4,9 \\
\hline & \multirow{3}{*}{ III дек. вересня } & 15 & 1,1 & 3,2 & 4,4 \\
\hline & & 30 & 1,4 & 2,6 & 4,3 \\
\hline & & 60 & 1,5 & 2,2 & 4,1 \\
\hline \multirow{9}{*}{ 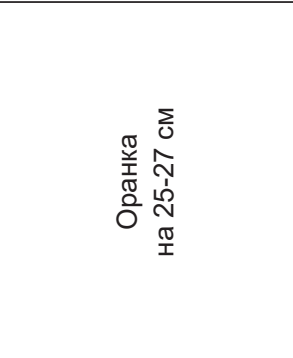 } & \multirow{3}{*}{ І дек. вересня } & 15 & 1,5 & 3,8 & 4,8 \\
\hline & & 30 & 1,6 & 3,1 & 5,0 \\
\hline & & 60 & 1,7 & 2,9 & 5,1 \\
\hline & \multirow{3}{*}{ II дек. вересня } & 15 & 1,4 & 3,2 & 5,2 \\
\hline & & 30 & 1,4 & 2,8 & 5,0 \\
\hline & & 60 & 1,5 & 2,4 & 5,0 \\
\hline & \multirow{3}{*}{ III дек. вересня } & 15 & 1,3 & 3,1 & 4,7 \\
\hline & & 30 & 1,3 & 2,9 & 4,6 \\
\hline & & 60 & 1,4 & 2,4 & 4,7 \\
\hline
\end{tabular}


приріст рослин у висоту коливався від 4,1-4,7 см за сівби у III декаду вересня до 4,8-5,4 cм/добу за сівби у I декаду вересня.

Більш повну інформацію про інтенсивність ростових процесів у посівах ріпаку озимого у зв'язку з факторами, що вивчали, забезпечує динаміка накопичення вегетативної маси рослин.

Нашими дослідженнями встановлено тісний зв'язок між накопиченням біомаси ріпаку озимого і обробітком ґрунту вже з перших етапів розвитку рослин у весняний період вегетації. Починаючи з фази стеблування накопичення зеленої маси посівами ріпаку озимого більш інтенсивно відбувається у варіантах з оранкою. На цих посівах було сфрормовано 3,5 кг/м² біомаси, що на 20,7\% більше порівняно з дискуванням.

Таку ж тенденцію спостерігали і в подальших фазах розвитку ріпаку. Найбільшу кількість надземної біомаси накопичували рослини першого строку сівби. Різниця між строками в 10 днів може призводити до різкого зменшення врожаю біомаси. Вже з фази стеблування спостерігали чітку тенденцію до наростання меншої кількості сирої надземної біомаси на посівах II та III строків сівби порівняно з І строком. Так, у зазначену фразу посіви ріпаку, висіяні у I декаду вересня перевищували за накопиченням зеленої маси посіви II та III строків сівби на 13,9-16,7\%.

Найбільшу кількість зеленої маси - 7,0 кг/м² накопичено у фазу цвітіння на посівах I строку сівби. Посіви у II та III декади вересня поступались за її кількістю на 14,3$20,0 \%$. У середньому за роки досліджень найбільшу величину біомаси нагромаджували посіви за звичайного рядкового способу сівби з максимумом у фразу цвітіння.
Так, починаючи з відновлення вегетації до цвітіння рослини ріпаку озимого найбільшу кількість надземної маси - 4,4-7,5 кг/м² накопичували за звичайного рядкового способу сівби. За збільшення ширини міжрядь вихід зеленої біомаси з одиниці площі зменшувався. А саме, за сівби з шириною міжрядь 30 см ії̈ сформувалось менше на 20,0-31,8\%, а 60 см до 2,2-5,0 кг/м² або на 33,3-50,0\% порівняно з рядковим способом сівби.

Аналізом комплексного впливу дії досліджуваних фракторів визначено, що найбільш несприятливо умови для розвитку рослин ріпаку складаються за сівби у III декаду вересня 3 шириною міжрядь 60 см по фону дискування на 12-14 см. Ці посіви, протягом весняної вегетації, найменше накопичували зеленої маси на одиниці площі - 1,83-4,57 кг/м² (табл. 2).

За рахунок оптимізації окремих елементів технології вирощування ріпаку складаються умови, які сприяють кращому росту та розвитку рослин культури. У наших дослідженнях оранка на 25-27 см, сівба звичайним рядковим способом у I декаду вересня сприяли формуванню найбільшої кількості сирої надземної біомаси $5,25-9,22 \mathrm{\kappa r} / \mathrm{M}^{2}$.

Запізнення з сівбою також негативно впливало на інтенсивність накопичення надземної біомаси. Так, посіви висіяні у I декаду вересня забезпечували серед-

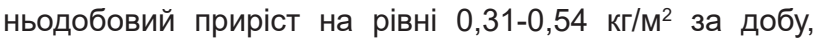
і мали перевагу над посівами у II та III декади, де цей показник коливався в межах 0,28-0,47 та 0,27-0,42 кг/

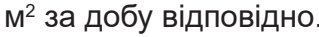

Аналогічно наростанню сирої біомаси відбувалося накопичення сухої речовини посівами ріпаку озимого. Під впливом основного обробітку ґрунту в період весня-

Таблиця 2 - Динаміка накопичення зеленої біомаси рослин ріпаку залежно від досліджуваних факторів, кг/м² (середнє за 2013-2015 рр.)

\begin{tabular}{|c|c|c|c|c|c|}
\hline \multirow{2}{*}{ Обробіток ґрунту, А } & \multirow{2}{*}{ Строк сівби, В } & \multirow{2}{*}{$\begin{array}{c}\text { Ширина } \\
\text { міжрядь, см, C }\end{array}$} & \multicolumn{3}{|c|}{ Фаза розвитку рослин } \\
\hline & & & Стеблуван-ня & Бутонізація & Цвітіння \\
\hline \multirow{9}{*}{ 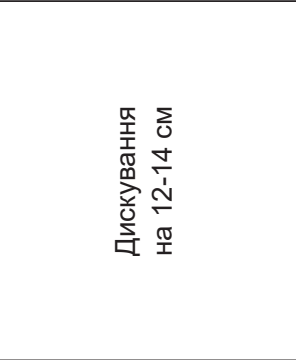 } & \multirow{3}{*}{ І дек. вересня } & 15 & 4,17 & 5,07 & 8,01 \\
\hline & & 30 & 2,92 & 3,73 & 6,12 \\
\hline & & 60 & 2,66 & 3,40 & 5,02 \\
\hline & \multirow{3}{*}{ II дек. вересня } & 15 & 4,01 & 4,79 & 6,89 \\
\hline & & 30 & 2,57 & 3,55 & 5,50 \\
\hline & & 60 & 1,87 & 3,00 & 4,55 \\
\hline & \multirow{3}{*}{ III дек. вересня } & 15 & 3,92 & 4,12 & 6,18 \\
\hline & & 30 & 2,53 & 3,12 & 4,92 \\
\hline & & 60 & 1,83 & 2,95 & 4,57 \\
\hline \multirow{9}{*}{ 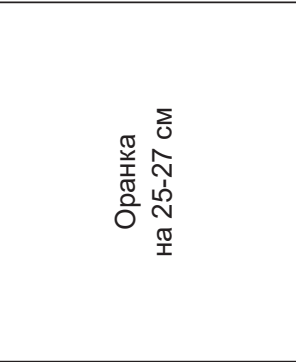 } & \multirow{3}{*}{ І дек. вересня } & 15 & 5,25 & 5,76 & 9,22 \\
\hline & & 30 & 3,62 & 4,54 & 7,08 \\
\hline & & 60 & 2,77 & 4,11 & 6,33 \\
\hline & \multirow{3}{*}{ II дек. вересня } & 15 & 4,68 & 5,05 & 7,93 \\
\hline & & 30 & 3,50 & 4,25 & 6,54 \\
\hline & & 60 & 2,11 & 2,80 & 4,45 \\
\hline & \multirow{3}{*}{ III дек. вересня } & 15 & 4,62 & 4,70 & 7,06 \\
\hline & & 30 & 3,05 & 3,75 & 5,80 \\
\hline & & 60 & 2,10 & 3,28 & 5,09 \\
\hline \multicolumn{6}{|c|}{ Оцінка істотності часткових відмінностей } \\
\hline \multirow{3}{*}{\multicolumn{2}{|c|}{$\mathrm{HIP}_{05}$}} & $A$ & 0,4 & 0,4 & 0,6 \\
\hline & & $B$ & 0,3 & 0,4 & 0,9 \\
\hline & & C & 0,9 & 0,6 & 1,1 \\
\hline
\end{tabular}


ної вегетації воно коливалося в межах від 177,1-968,9 г/

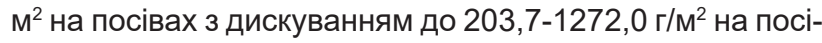
вах $з$ оранкою.

Найбільш активно накопичення сухої речовини рослинами ріпаку відбувалось у фазу цвітіння. Так, на посівах по фону оранки ії̈ кількість у фазу стеблування склала 201,2-488,3 г/м², у фразу бутонізації 333,2-639,5 г/ $\mathrm{M}^{2}$, а у фразу цвітіння - 627,7-1272,0 г/M².

На вихід сухої речовини з одиниці площі впливали строки сівби. За сівби у I декаду вересня посіви ріпаку озимого у фразу цвітіння сорормували найбільшу кількість

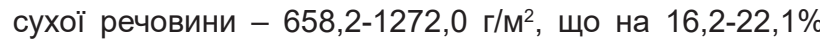
більше порівняно з посівами у II та III декади вересня.

За збільшення ширини міжрядь до 60 см активність накопичення сухої речовини зменшується. Так, посіви звичайним рядковим способом у фразу цвітіння сформували 729,8-1272,0 г/м² сухої речовини, що на 17,3-29,5\% перевищувало широкорядні посіви.

Максимальну кількість сухої речовини 1272,0 г/M² накопичено рослинами у фазу цвітіння за сівби у I декаду вересня, звичайним рядковим способом по фону оранки.

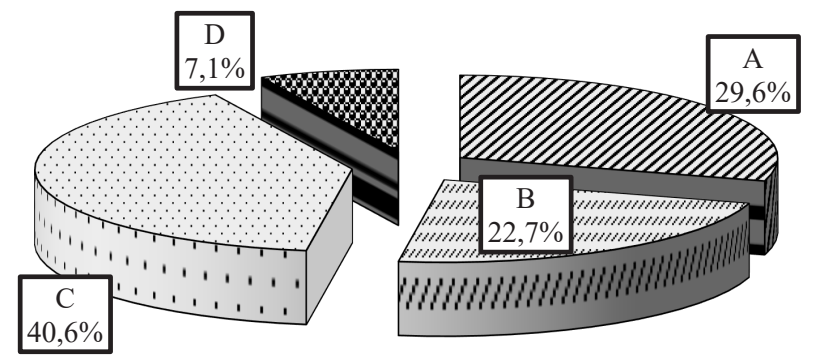

Puc. 3. Дольова частка впливу досліджуваних факторів на динаміку накопичення надземної маси

Примітка: A - обробіток ґрунту; В - строк сівби; C - спосіб сівби; D - сумарна дольова участь взаємодій.

На основі аналізу супутніх спостережень за розвитком рослин ріпаку було виявлено, що найбільш інтенсивно формування вегетативних органів відбувається у міжсразний період бутонізація - цвітіння. Саме в цю фазу формується потенціал майбутнього врожаю. Тому нами була поставлена задача виявити частку впливу факторів вирощування на накопичення надземної біомаси рослинами (рис. 3).

Аналізуючи отримані дані за роки досліджень, нами виявлено, що найбільш впливовим - 40,6\% у формуванні надземної маси ріпаку озимого був спосіб сівби. Другим за значимістю - 29,6\% визначено обробіток ґрунту, а частка впливу строку сівби склала 22,7\%. Таким чином, всі досліджувані фактори значно впливають на інтенсивність та накопичення надземної біомаси, тому їх регулювання та доведення до оптимальних параметрів $€$ необхідним для збільшення продуктивності посівів ріпаку озимого.

Висновки. Дослідженнями з визначення інтенсивності наростання надземної маси ріпаку озимого сорту Чемпіон України залежно від фракторів вирощування встановлено, що найбільшою вона формується за сівби і I декаду вересня звичайним рядковим способом по фону оранки на 25-27 см. У зазначеному варіанті у фразу стеблування кількість сухої речовини склала 488,3,

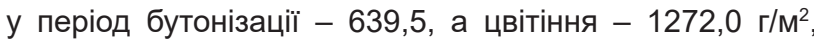
що в останню фразу перевищило посіви у II і II декади вересня на $16,2-22,1 \%$.

Максимальної висоти рослини ріпаку озимого досягли у фразу цвітіння - 126,4-135,3 см з різницею між варіантами 8,9 см на користь оранки.

Дольова частка впливу досліджуваних факторів на динаміку накопичення надземної біомаси ріпаком озимим визначена наступним чином: спосіб сівби 40,6\%, обробіток грунту - 29,6 та строк сівби - 22,7\%.

Для накопичення значної кількості надземної біомаси та наступного формування високої продуктивності ріпаку озимого в якості основного обробітку грунту проводити оранку на 25-27 см, сівбу у I декаду вересня звичайним рядковим способом.

\section{СПИСОК ВИКОРИСТАНОÏ ЛІТЕРАТУРИ:}

1. Шевелуха В. С. Периодичность роста сельскохозяйственных растений и пути ее регулирования. М.: Колос, 1980. 455 с.

2. Биология развития растений / Под ред. М. Х. Чайлахяна. М.: Наука, 1975. 229 с.

3. Ничипорович А. А. Реализация регуляторной функции света в жизнедеятельности растений как целого и в его продуктивности. Фоторегуляция метаболизма и морфогенеза растений. М.: Наука, 1975. C. $56-61$.

4. Ничипорович А. А. Фотосинтетическая деятельность растений и пути повышения их продуктивности. Теоретические основы фотосинтетической продуктивности. М.: Наука, 1972. С. 12-16.

5. Гупало П. И. Возрастные изменения растений и их значение в растениеводстве. М.: Наука, 1969. $167 \mathrm{c}$.

6. Кефели В. И. Рост растений. М.: Колос, 1984. 175 с.

7. Олійні та ефіроолійні культури / За ред. М. М. Городнього. К.: Урожай, 1970. 276 с.

8. Методические рекомендации по проведению полевых опытов в условиях орошения УССР. Днепропетровск, 1985. 134 с.

9. Ушкаренко В. О., Нікішенко В. Л, Голобородько С. П., Коковіхін С. В. Дисперсійний і кореляційний аналіз результатів польових дослідів : монографрія. Херсон : Айлант, 2009. 372 с

\section{REFERENCES:}

1. Shevelukha, V.S. (1980). Periodichnost' rosta sel'skokhozyaystvennykh rasteniy i puti yeye regulirovaniya [Periodicity of growth of agricultural plants and ways of its regulation]. M.: Kolos, 455 [in Russian].

2. Chaylakhyana, M.Kh. (Ed). (1975). Biologiya razvitiya rasteniy [Biology of plant development]. M.: Nauka, 229 [in Russian].

3. Nichiporovich, A.A. (1975). Realizatsiya regulyatornoy funktsii sveta $v$ zhiznedeyatel'nosti rasteniy kak tselogo i $v$ yego produktivnosti [Realization of the regulatory function of light in the life of plants as a whole and in its productivity]. Fotoregulyatsiya metabolizma i morfogeneza rasteniy - Photoregulation of plant 
metabolism and morphogenesis. M.: Nauka, 56-61 [in Russian].

4. Nichiporovich, A.A. (1972). Fotosinteticheskaya deyatel'nost' rasteniy i puti povysheniya ikh produktivnosti [Photosynthetic activity of plants and ways to increase their productivity]. Teoreticheskiye osnovy fotosinteticheskoy produktivnosti - Theoretical foundations of photosynthetic productivity. M.: Nauka, 12-16 [in Russian].

5. Gupalo, P.I. (1969). Vozrastnyye izmeneniya rasteniy $i$ ikh znacheniye $v$ rasteniyevodstve [Age-related changes in plants and their importance in plant growing]. M.: Nauka, 167 [in Russian].

6. Kefeli, V.I. (1984). Rost rasteniy [Plant growth]. M.: Kolos, 175 [in Russian].

7. Horodn'oho, M.M. (1970). Oliyni ta efirooliyni kul'tury [Oil and essential oil crops]. K.: Urozhay, 276 [in Ukrainian].

8. Metodicheskiye rekomendatsii po provedeniyu polevykh opytov $v$ usloviyakh orosheniya USSR (1985). [Methodical recommendations for carrying out field experiments in the conditions of irrigation of the Ukrainian SSR]. Dnepropetrovsk, 134 [in Russian].

9. Ushkarenko, V.O., Nikishenko, V.L, Holoborod'ko, S.P., Kokovikhin, S.V. (2009). Dyspersiynyy i korelyatsiynyy analiz rezul'tativ pol'ovykh doslidiv [Dispersion and correlation analysis of the results of field experiments]. Kherson: Aylant, 372 [in Ukrainian].

Гамаюнова В.В., Гаро І.М. Вплив факторів вирощування на наростання надземної біомаси ріпаком озимим в умовах Лісостепу України

Наведено дані досліджень з наростання надземної маси ріпаком озимим сорту Чемпіон за вирощування культури на чорноземі звичайному в умовах Лісостепу України впродовж 2013-2015 рр. Мета. Метою досліджень передбачали визначити вплив способу і глибини основного обробітку ґрунту під сівбу ріпаку озимого на окремі його показники, зокрема на висоту рослин та накопичення надземної сирої і сухої речовини. Методи. При проведенні досліджень використовували загальноприйняті методи, методики та ДСТУ. Динаміку росту та розвитку ріпаку залежно від досліджуваних фракторів визначали по трьом основним фразам - стеблування, бутонізація та цвітіння рослин ріпаку озимого згідно методики проведення досліджень. Результати. Визначено, що найбільших значень висота рослин, кількість накопиченої сирої і сухої надземної біомаси досягають у фразу цвітіння по фону оранки на 25-27 см за сівби звичайним рядковим способом у І декаду вересня з відновлення вегетації до цвітіння рослини ріпаку озимого найбільшу кількість надземної маси - 4,4-7,5 кг/ $\mathrm{M}^{2}$ накопичували за звичайного рядкового способу сівби. За збільшення ширини міжрядь вихід зеленої біомаси з одиниці площі зменшувався. А саме, за сівби з шириною міжрядь 30 см ії̈ сформувалось сирої менше на 20,0-

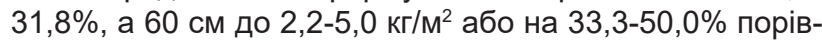
няно з рядковим способом сівби. За сівби у більш пізні строки - у II та III декади вересня 3 шириною міжрядь
30 і 60 см та по фрону дискування наростання висоти рослин та накопичення ними надземної біомаси відбувається менш інтенсивно. Висновок. Максимальної висоти рослини ріпаку озимого досягли у фазу цвітіння - 126,4-135,3 см з різницею між варіантами 8,9 см на користь оранки. Визначено, що в середньому за роки досліджень на формування надземної маси рослинами ріпаку озимого найбільше впливав спосіб сівби, частка якого склала 40,6 \%, обробітку ґрунту - 29,6 \%, на строк сівби припадало 22,7\%.

Ключові слова: ріпак озимий, строк і спосіб сівби, основний обробіток грунту, висота рослин, наростання надземної біомаси, динаміка, частка впливу.

Gamayunova V.V., Garo I.M. Influence of cultivation factors on the growth of aboveground biomass by winter rape in the conditions of the Forest-Steppe of Ukraine

The data of researches on increase of above-ground mass by winter rape of the Champion grade for cultivation of culture on chernozem usual in the conditions of Foreststeppe of Ukraine during 2013-2015 are resulted. The aim of the research was to determine the influence of the method and depth of the main tillage for sowing winter oilseed rape on some of its indicators, in particular on the height of plants and the accumulation of aboveground raw and dry matter. Methods. Commonly used methods, techniques and DSTU were used in the research. The dynamics of growth and development of rapeseed, depending on the studied factors, was determined by three main phases - stalking, budding and flowering of winter rapeseed plants according to the research methodology. Results. It is determined that the largest values of plant height, the amount of accumulated raw and dry aboveground biomass reach the flowering phase on the background of plowing by $25-27 \mathrm{~cm}$ for sowing in the usual row method in the first decade of September, $4-7.5 \mathrm{~kg} / \mathrm{m}^{2}$ was accumulated by the usual row method of sowing. As the row spacing increased, the yield of green biomass per unit area decreased. Namely, when sowing with a row spacing of $30 \mathrm{~cm}$, it was formed raw less by $20.0-31.8 \%$, and $60 \mathrm{~cm}$ to $2.2-5.0 \mathrm{~kg} / \mathrm{m}^{2}$ or $33.3-50.0 \%$ compared to row sowing method. For sowing at a later date - in the II and III decades of September with a row spacing of 30 and $60 \mathrm{~cm}$ and against the background of disking, the increase in plant height and their accumulation of aboveground biomass is less intense. Conclusion. The maximum height of winter rape plants was reached in the flowering phase - 126.4$135.3 \mathrm{~cm}$ with a difference between the options of $8.9 \mathrm{~cm}$ in favor of plowing. It is determined that on average over the years of research the formation of aboveground mass by winter rape plants was most influenced by the method of sowing, the share of which was $40.6 \%$, tillage $-29.6 \%$, the sowing period accounted for $22.7 \%$.

Key words: winter rape, term and method of sowing, main tillage, plant height, increase of aboveground biomass, dynamics, share of influence. 